\title{
PIOTR MICKIEWICZ
}

ORCID: 0000-0002-3533-337X

\section{DANIEL DAMIAN KASPRZYCKI}

ORCID: 0000-0002-7412-3447

DOI: 10.4467/20801335PBW.21.019.14296

\section{Od „konfliktu hybrydowego” do działań konwencjonalnych? Koncepcja oddziaływania militarnego Rosji, ze szczególnym uwzględnieniem zmian po 2018 roku}

W publicystyce poświęconej współczesnym konfliktom zbrojnym rosyjskie działania na Ukrainie, zwłaszcza na Półwyspie Krymskim, nazwano wojną hybrydową. W rosyjskiej myśli wojskowej pojęcie „wojna hybrydowa” (wykreowane przez część anglosaskich analityków, przede wszystkim Franka Hoffmana ${ }^{1}$ ) oznaczało połączenie metod militarnych i niemilitarnych, umożliwiające osiągnięcie celu operacyjnego lub strategicznego. Rosjanie nie odnajdywali w tej koncepcji żadnego novum i nie traktowali jej jako kompletnej wizji wojny nowej generacji czy nowego typu. Pojęcie „wojna hybrydowa" wykorzystano nawet w narracji politycznej, wskazując, że jest to - głównie amerykański - sposób prowadzenia działań, mający na celu obalenie „niewygodnych" reżimów politycznych. W tym tonie wypowiadał się m.in. minister obrony Federacji Rosyjskiej (FR) Siergiej Szojgu: Nasi zachodni koledzy uwielbiaja oskarżać Rosje o prowadzenie jakiejś tam wojny hybrydowej, ale prawdziwe wojny hybrydowe prowadzi Zachód ${ }^{2}$ (tłum. aut.). Uznano także, że w obecnej sytuacji międzynarodowej większe znaczenie dla ochrony interesów narodowych Rosji ma jej zdolność do interwencji poza granicami kraju. To wymagało zdobycia możliwości prowadzenia

W.J. Nemeth, Future War and Chechnya: A Case for Hybrid Warfare, Monterey 2002; F. Hoffman, Conflict in the 21st century: The rise of hybrid wars, Arlington 2007; J.J. McCuen, Hybrid Wars, „Military Review” 2008, nr 2, s. 107-113.

2 Сергей Шойгу рассказал, как спасали российскую, 22 IX 2019 r., https://www.mk.ru/politics/2019/09/22/sergey-shoygu-rasskazal-kak-spasali-rossiyskuyu-armiyu.html [dostęp: 22 IX 2019]. 
kompleksowych działań polityczno-militarnych, które - wzorem amerykańskich koncepcji Prompt Global Strike i Globally Integrated Operations - nazwano „działaniami zintegrowanymi".

Przedmiotem badań podjętych w niniejszym opracowaniu jest ewolucja rosyjskiej koncepcji „wojny nowego typu”, będąca wynikiem doświadczeń wyniesionych z działań prowadzonych na Ukrainie oraz - w mniejszym stopniu - z aktywności militarnej w Syrii. Celem tych badań jest wykazanie, że formuła działań polityczno-militarnych, powszechnie określana mianem wojny hybrydowej lub działań hybrydowych, nie oddaje $\mathrm{w}$ pełni rosyjskiej koncepcji prowadzenia polityki międzynarodowej z wykorzystaniem potencjału militarnego. Autorzy przyjęli hipotezę roboczą, że obowiązująca w Rosji wizja wojny nowego typu stanowi połączenie różnych przedsięwzięć niemilitarnych i militarnych, bliższych pojęciom „działania asymetryczne” lub „działania nieliniowe". Celem tych działań jest zwiększenie możliwości antydostępowych, zakładające sukcesywne odsuwanie strefy obrony od granic FR i budowanie (odtworzenie) buforu bezpieczeństwa wokół granic państwa (strategia aktywnej obrony), oraz kształtowanie regionalnego ładu międzynarodowego w obszarach ulokowania rosyjskich interesów narodowych zgodnie z oczekiwaniami tego państwa (strategia działań ograniczonych). Osiągnięcie tak zdefiniowanego celu wymaga dysponowania przez FR potencjałem pozwalającym na ograniczenie działań reaktywnych lub odwetowych, podejmowanych zarówno przez państwa poddane takiemu oddziaływaniu, jak i społeczność międzynarodową, do poziomu aprobowanego przez Moskwę. Przyjęta hipoteza robocza została poddana weryfikacji, w ramach której autorzy przeanalizowali problemy szczegółowe dotyczące:

1) roli środków oddziaływania wykorzystywanych w tzw. działaniach zintegrowanych, określanych jako instrumentarium hybrydowe;

2) roli działań pośrednich, zastępczych i specjalnych oraz klasycznych operacji konwencjonalnych w rosyjskiej polityce bezpieczeństwa;

3) znaczenia koncepcji zewnętrznego pierścienia obrony oraz strategii aktywnej obrony w rosyjskiej doktrynie wojennej;

4) roli systemowej reformy rosyjskich sił zbrojnych przeprowadzanej $\mathrm{w}$ celu osiągnięcia zdolności do prowadzenia działań zintegrowanych $\mathrm{w}$ ramach przedsięwzięć określanych jako budowa zewnętrznego pierścienia obrony oraz zdolności do realizowania strategii działań ograniczonych.

Autorzy zrezygnowali z koncentrowania uwagi na specyfice działań hybrydowych, gdyż uznali, że jest to zagadnienie dobrze opracowane, także przez polskie środowisko naukowe ${ }^{3}$. Ponadto $\mathrm{w}$ rosyjskiej polityce bezpieczeństwa zakres przedsięwzięć

3 Zagadnienie, o którym mowa, było wielokrotnie omawiane także na łamach „Przeglądu Bezpieczeństwa Wewnętrznego". 
określanych jako oddziaływanie PEMSI ${ }^{4}$ oraz tzw. etapy prowadzenia działań hybrydowych ${ }^{5}$ nie zostały zmodyfikowane.

Przyjęte podejście wpłynęło na dobór metod badawczych, wśród których najważniejsze były: analiza dokumentów i dorobku badawczego rosyjskich strategów wojskowych oraz analiza czynnikowa $\mathrm{z}$ elementami analizy historycznej. Celem badań było wskazanie czynników determinujących sposób realizowania polityki bezpieczeństwa przez FR, a w konsekwencji pokazanie przeobrażeń doktryny wojskowej i koncepcji wykorzystania potencjału sił zbrojnych. Jest to podejście odmienne od dotychczas przeprowadzonych analiz o tej tematyce, które koncentrowały się na zagadnieniu hybrydowości form oddziaływania międzynarodowego, a ostatnio - na budowie potencjału antydostępowego.

Dyskurs naukowy dotyczący roli poszczególnych środków oddziaływania wykorzystywanych w ramach działań zintegrowanych został zdominowany przez tezy autorstwa Hoffmana, a w Polsce głównie przez środowiska skupione wokół Centrum Doktryn i Szkoleń Ministerstwa Obrony Narodowej oraz ośrodków analitycznych zajmujących się problematyką militarną lub Wspólnotą Niepodległych Państw. Dorobek w tym obszarze badań obejmuje przede wszystkim udokumentowanie działań uznawanych za hybrydowe, wskazanie cech, które je wyróżniają, zwłaszcza w odniesieniu do działań asymetrycznych i przeciwnika asymetrycznego. Wnioski zaprezentowane w niniejszym artykule zostały oparte na analizie rosyjskich działań na Półwyspie Krymskim i w Donbasie, w minimalnym stopniu przeanalizowano także działania prowadzone w Syrii.

W przypadku drugiego problemu szczegółowego wiodącym podejściem badawczym jest tradycyjne postrzeganie koncepcji A2/AD ${ }^{6}$ (zgodnie ze szkołą amerykańską) i ocena rosyjskiego potencjału bojowego pod kątem możliwości prowadzenia skutecznych działań antydostępowych. W europejskiej literaturze przedmiotu, w tym polskiej, badacze w ograniczonym stopniu odnoszą się do problematyki podnoszonej przez rosyjskich strategów wojskowych w związku z wizją wojny nowego typu. Jest to zazwyczaj prezentacja autorskich koncepcji poszczególnych środowisk i badaczy, bez uwzględnienia ich wpływu na całokształt polityki bezpieczeństwa. Niniejsze opracowanie jest próbą ukazania uwarunkowań i zakresu modyfikacji tej koncepcji w kontekście

4 PEMSI (ang. politics, economy, military, social affairs, information technology) - skrót oznaczający działania w obszarach: politycznym, ekonomicznym, militarnym, społecznym i informacyjnym (przyp. red.). Pojęcie i strategię PEMSI upowszechniają w Polsce oficerowie z Centrum Doktryn i Analiz MON. Zob. „Przegląd Sił Zbrojnych” 2017, nr 4; C. Pawlak, Konflikt na wschodzie Ukrainy sztandarowym przykładem działań hybrydowych, „Rocznik Bezpieczeństwa Międzynarodowego” 2017, nr 1, s. 268-287; J. Keplin, C. Pawlak, Hybrydowość wyzwaniem dla bezpieczeństwa przyszłości, „Biuletyn CDiS SZ” 2016, nr 2, s. 5-7; C. Pawlak, J. Keplin, Aneksja Krymu w kontekście działań hybrydowych, „Kwartalnik Bellona” 2016, nr 3, s. 23-32.

5 В. Герасимов, Ценность науки в предвидении. Новые вызовы требуют переосмыстить бормы и способы ведения боевых действий, „Военно-промышленный курьер”, 26 II 2013 r., http://www.vpk-news.ru/articles/14632 [dostęp: 10 II 2018].

6 Skrót od Anti-Access/Area Denial oznaczający systemy antydostępowe (przyp. red.). 
polityki bezpieczeństwa FR oraz formuły przygotowania rosyjskich sił zbrojnych do prowadzenia działań bojowych, jaką wdraża Sztab Generalny Sił Zbrojnych FR kierowany przez gen. Walerija Gierasimowa.

\section{Ewolucja koncepcji wykorzystania sił zbrojnych w polityce bezpieczeństwa Federacji Rosyjskiej po 2018 roku}

Rosyjska polityka bezpieczeństwa jest oparta na kilku niezmiennych założeniach. Jej podstawą doktrynalną jest, wywodząca się z teorii realizmu politycznego, koncepcja bezpieczeństwa, przyjmująca, że podmiotem jest państwo jako gracz międzynarodo$\mathrm{wy}^{7}$. Tak zwana potęga państwa ${ }^{8}$, która we wspomnianej teorii odgrywa istotną rolę, jest natomiast postrzegana przez pryzmat koncepcji geopolitycznej Wieniamina Siemionowa Tien-Szańskiego. Za cel polityki bezpieczeństwa uznawał on zdolność do zapewniania władzy centralnej kontroli nad obszarem państwa, ochronę „centrów” decydujących o potędze państwa oraz zdominowanie obszarów ulokowania interesów narodowych, zwłaszcza tych zlokalizowanych wokół zewnętrznych granic państwa9 ${ }^{9}$ Powyższe założenia powodują, że w polityce Rosji koncepcja tzw. działań zintegrowanych jest sprowadzona do wykorzystania elementów swoistego „zbioru” instrumentów, pozwalających na realizację - w sposób maksymalnie ograniczający możliwość reakcji na rosyjskie działania - celów politycznych na określonym obszarze. $Z$ tego względu preferowanym instrumentarium są działania niemilitarne i nieagresywne działania komponentu militarnego, jednak w sytuacji braku możliwości ich prowadzenia podstawowym środkiem pozostaje instrumentarium militarne. Dlatego też potencjał militarny FR musi być rozbudowywany i powinien dysponować zdolnością do szybkiej reakcji na zaistnienie zdarzeń ograniczających tak rozumiane bezpieczeństwo państwa (niemożność osiągnięcia interesów narodowych i zagrożenie integralności państwa).

Analiza doboru instrumentarium wykorzystanego na Krymie i we wschodniej Ukrainie pozwala stwierdzić, że są to przykłady klasycznego zastosowania koncepcji działań zintegrowanych. Priorytetowe potraktowanie działań niemilitarnych na obszarze Półwyspu Krymskiego wynikało z przeprowadzonych analiz i założenia, że uwarunkowania społeczne pozwolą na osiągnięcie celów środkami niemilitarnymi. Uznano również, że konwencjonalne wykorzystanie instrumentarium militarnego może wywołać negatywną reakcję społeczności międzynarodowej. Nie był to główny czynnik

Zob. szerzej: J. Czaputowicz, Teorie stosunków międzynarodowych. Krytyka i systematyzacja, Warszawa 2008, s. 58.

8 Zob. szerzej: A. Wojciuk, Dylemat potęgi. Praktyczna teoria stosunków międzynarodowych, Warszawa 2010, s. 27-35.

9 P. Mickiewicz, W poszukiwaniu teoretycznych podstaw rosyjskiego myślenia strategicznego ery W. Putina, „Rocznik Bezpieczeństwa Międzynarodowego” 2018, nr 2, s. 39-56. 
decydujący o charakterze rosyjskich działań, ale został wzięty pod uwagę. We wschodniej części Ukrainy postawa lokalnej społeczności była inna, dlatego wykorzystano zarówno potencjał protestu, jak i potencjał militarny.

Tab. 1. Korelacja militarnych i niemilitarnych środków oddziaływania według gen. Walerija Gierasimowa (koncepcja z 2013 r.).

\begin{tabular}{|c|c|c|c|}
\hline $\begin{array}{c}\text { Etap } \\
\text { operacji }\end{array}$ & Działania niemilitarne & $\begin{array}{c}\text { Etap } \\
\text { operacji }\end{array}$ & Działania militarne \\
\hline $1-2$ & $\begin{array}{l}\text { tworzenie wewnątrzpaństwowej } \\
\text { opozycji w państwie, które jest celem } \\
\text { agresji }\end{array}$ & $1-6$ & $\begin{array}{l}\text { prowadzenie działań destabilizujących } \\
\text { sytuację polityczną }\end{array}$ \\
\hline $1-3$ & $\begin{array}{l}\text { budowanie koalicji i potencjału } \\
\text { protestu w państwie, które jest celem } \\
\text { agresji }\end{array}$ & \multirow[t]{2}{*}{$1-4$} & \multirow{2}{*}{$\begin{array}{l}\text { aktywna polityka odstraszania } \\
\text { (redukowanie możliwości udzielenia } \\
\text { wsparcia państwu, które jest celem } \\
\text { agresji) }\end{array}$} \\
\hline $2-3$ & wywieranie presji politycznej & & \\
\hline $2-4$ & $\begin{array}{l}\text { wywieranie presji polityczno-ekono- } \\
\text { micznej }\end{array}$ & \multirow[t]{2}{*}{$3-4$} & \multirow{2}{*}{$\begin{array}{l}\text { strategiczne rozmieszczenie sił zbroj- } \\
\text { nych }\end{array}$} \\
\hline $3-4$ & kreowanie wystąpień opozycji & & \\
\hline 4 & blokada ekonomiczna & \multirow[b]{2}{*}{$4-5$} & \multirow{2}{*}{$\begin{array}{l}\text { przeprowadzenie operacji zapro- } \\
\text { wadzającej lub zapewniającej pokój } \\
\text { (stabilizacyjnej, humanitarnej, poko- } \\
\text { jowej) }\end{array}$} \\
\hline 5 & $\begin{array}{l}\text { wymuszenie procesu mobilizacji go- } \\
\text { spodarki; próba zmiany przywództwa } \\
\text { politycznego }\end{array}$ & & \\
\hline $5-6$ & $\begin{array}{l}\text { działania na rzecz deeskalacji konflik- } \\
\text { tu wewnętrznego w państwie, które } \\
\text { jest celem agresji }\end{array}$ & 6 & działania na rzecz budowania pokoju \\
\hline
\end{tabular}

Źródło: Opracowanie własne na podstawie: В. Герасимов, Ценность науки в предвидении. Новые вызовы требуют переосмыслить формы и способы ведения боевых действий, „Военно-промышленный курьер”, 26 II 2013 r., http://www.vpk-news.ru/articles/14632 [dostęp: 10 II 2018].

Istnieją przesłanki świadczące o tym, że rosyjscy wojskowi nie uznają działań hybrydowych za uniwersalną koncepcję wojny nowego typu. Wskazują na to wyniki analizy dotyczącej procesu modernizacji (jego zakresu i skali) rosyjskich sił zbrojnych oraz odmienne podejście do działań prowadzonych na Półwyspie Krymskim i w obwodach wschodniej Ukrainy. Jeszcze silniej potwierdzają tę tezę dwa inne zjawiska specyficzne rozumienie interesu narodowego przez rosyjski establishment polityczny oraz sposób definiowania pojęcia „bezpieczeństwo państwa”. W odniesieniu do odmienności działań prowadzonych na różnych obszarach Ukrainy należy podkreślić, że skuteczność operacji krymskiej w dużej mierze wynikała z odpowiedniego wykorzystania specyfiki społecznej, zwłaszcza uwarunkowań narodowościowych. Nieco inna struktura społeczna, jak również odmienne poglądy na kwestię przynależności państwowej prezentowane przez ludność obwodów ługańskiego i donieckiego uniemożliwiły powielenie tam scenariusza krymskiego i wymusiły użycie potencjału 
militarnego ${ }^{10}$. Ta sytuacja dowiodła, że "metoda krymska” (w postaci skoordynowanych działań PEMSI) nie może być traktowana jako jedyny sposób czy uniwersalna koncepcja prowadzenia operacji polityczno-militarnej. Dużo ważniejsze jest jednak postrzeganie potęgi państwa, któremu przyznaje się rangę mocarstwa globalnego, i zapewnienie mu bezpieczeństwa. Zgodnie z teorią Tien-Szańskiego dotyczącą funkcjonowania mocarstwa lądowego rosyjski potencjał militarny ma odgrywać rolę instrumentu służącego zarówno do odstraszania potencjalnych wrogów, jak i do realizacji interesów narodowych ${ }^{11}$. Federacja Rosyjska musi więc dysponować potencjałem bojowym adekwatnym do tego, jaki mają jej główni rywale polityczni, i być zdolna do prowadzenia operacji militarnych pozwalających na realizację i ochronę interesów strategicznych państwa. Należy się zgodzić z tezą, że porażka w wyścigu zbrojeń w latach 80. XX w. (zwłaszcza jej konsekwencje polityczne i ekonomiczne) spowodowała, że w późniejszych rosyjskich koncepcjach militarnych uwzględniono możliwość korzystania z różnych form działań pośrednich, zastępczych i specjalnych zamiast klasycznych operacji konwencjonalnych. Szczególną rolę przypisano działaniom sił specjalnych o charakterze dywersyjnym i sabotażowym, zdolnościom do działania w specyficznym środowisku naturalnym oraz mobilności poszczególnych oddziałów. Jest to widoczne przede wszystkim w realizowanym od 2014 r. procesie rozbudowy potencjału militarnego w rosyjskiej Arktyce. Początkowo ograniczono go do tworzenia systemu baz dla komponentów wojsk lądowych, sił morskich i powietrznych. Stacjonujące w nich oddziały miały być zdolne do obrony Jakucji i ulokowanych tam instalacji wydobywczych oraz do kontroli żeglugi na wybranych akwenach Oceanu Arktycznego. Dzięki kolejnym inwestycjom w rozwój systemu baz wojskowych oraz potencjału militarnego (13 lotnisk i 10 stacji radarowych pozwalających na monitorowanie ruchu morskiego i przestrzeni powietrznej Oceanu Arktycznego), jak również dzięki rozbudowie potencjału bojowego sił morskich i sił specjalnych możliwe stało się podejmowanie działań określanych jako zabezpieczenie strategiczne rosyjskich obszarów arktycznych ${ }^{12}$.

10 M. Kofman, M. Rojansky, A Closer look at Russia's 'Hybrid War', „Kennan Cable” 2015, nr 7, s. 4-5, https://www.files.ethz.ch/isn/190090/5-KENNAN\%20CABLE-ROJANSKY\%20KOFMAN.pdf [dostęp: 12 I 2021].

11 P. Mickiewicz, $W$ poszukiwaniu teoretycznych podstaw...

12 Poza klasycznymi związkami taktycznymi na obszarze Dowództwa Strategicznego Północ funkcjonują: oddział rozpoznania specjalnego, oddziały sił specjalnych przeznaczone do zwalczania i prowadzenia działań sabotażowo-dywersyjnych i walki radioelektronicznej (WRE), które mogą skutecznie zakłócać systemy obserwacji technicznej, nadzoru ruchu i łączności. Zob. szerzej: P. Mickiewicz, Rosyjska polityka arktyczna - próba zdominowania regionu czy instrument polityki bezpieczeństwa?, w: Geopolityka Rosji i obszaru postsowieckiego, L. Sykulski (red.), Warszawa 2020, s. 178-204; D.D. Kasprzycki, Militarny aspekt rosyjskiej obecności w Arktyce w kontekście regionalnego bezpieczeństwa do 2018 r., „Rocznik Bezpieczeństwa Międzynarodowego” 2019, nr 2, s. 190-216. Szczegółowe zestawienie sił wchodzących w skład Dowództwa Strategicznego Północ znajduje się na blogu Milkavkaz, na stronie Северный Флот, 7 VII 2017 r., http://milkavkaz.com/ index.php/voorujonnie-cili-racii/vmf/cf [dostęp: 10 III 2018]. 
Analiza środowiska bezpieczeństwa, ocena potencjału innych graczy międzynarodowych oraz doświadczenia płynące z tzw. kolorowych rewolucji na obszarze Wspólnoty Niepodległych Państw doprowadziły do sformułowania głównego założenia rosyjskiej polityki bezpieczeństwa, zgodnie z którym podstawową metodą wpływania na państwo rosyjskie i jego interesy będą różnorodne instrumenty asymetryczne (nieliniowe). To z kolei implikuje konieczność korzystania z metod adekwatnych do tego rodzaju działań. Po przeanalizowaniu poglądów współczesnych rosyjskich teoretyków wojskowości można założyć, że w przypadku konfrontacji z przeciwnikiem o porównywalnym lub większym potencjale, jak również w sytuacji, w której może dojść do niekontrolowanej eskalacji konfliktu, Rosja będzie stosować różne działania pośrednie ${ }^{13}$. Powinny one przyjąć postać działań mieszczących się w ramach szeroko interpretowanego prawa dotyczącego konfliktów zbrojnych czy też pokojowego wykorzystania potencjału bojowego oraz działań ograniczających możliwość wskazania ich kreatora (cyberataki, różne formy oddziaływania radioelektronicznego, niszczenie obiektów w przestrzeni międzynarodowej). Natomiast w przypadku konfrontacji z przeciwnikiem o mniejszym potencjale prawdopodobne jest przeprowadzenie klasycznej operacji militarnej, która będzie sankcjonowana za pomocą stosownej interpretacji prawa międzynarodowego (prawo do samostanowienia, operacja humanitarna, ochrona ludności i jej praw itp.). Zrealizowanie takiej operacji może być również uzasadniane zaistnieniem, wykreowanej przez państwo rosyjskie, destabilizacji w państwie, które jest obiektem agresji.

Celem współczesnych operacji militarnych powinno być nie tyle opanowanie terenu, ile uniemożliwienie przeciwnikowi prowadzenia działań obronnych. Można to osiągnąć przez udaremnienie działania jego siłom zbrojnym, zniechęcenie społeczeństwa do prowadzenia wojny obronnej oraz ograniczenie do minimum możliwości ekonomicznych państwa, które jest celem agresji ${ }^{14}$. Skutkiem prowadzonych równolegle działań politycznych ma być natomiast dyplomatyczne wyizolowanie tego państwa ze społeczności międzynarodowej.

Zgodnie z przyjętymi założeniami rosyjski potencjał bojowy powinien zapewniać możliwość przeprowadzania precyzyjnych uderzeń na obiekty infrastruktury krytycznej i decydującej o sposobie funkcjonowania społeczeństwa i gospodarki państwa będącego obiektem agresji oraz zrealizowania klasycznej (kinetycznej) operacji militarnej ${ }^{15}$. Uznano, że celami dla broni precyzyjnej są obiekty, przede wszystkim systemy

13 Zob. szerzej: Rosyjska myśl strategiczna i potencjał militarny w XXI wieku, P. Mickiewicz (red.), Warszawa 2018.

14 П.А. Дульнев, В.Г. Ковалев, Л.Н. Ильин, Асимметричное противодействие в сетецентрической войне, „Военная мысль” 2011, nr 10, s. 3-8, http://militaryarticle.ru/voennaya-mysl/2011-vm/10357-asimmetrichnoe-protivodejstvie-v-setecentricheskoj [dostęp: $11 \mathrm{X}$ 2019]; С.Г. Чекинов, С.А. Богданов, Асимметричные действия по обеспечению военной безопасности России, „Военная мысль” 2010, nr 3, s. 13-22, http://militaryarticle.ru/voennaya-mysl/2010-vm/10291-asimmetrichnye-dejstvija-po-obespecheniju-voennoj [dostęp: 10 X 2019].

15 Równocześnie ma być on zdolny do prowadzenia działań A2/AD. 
wykorzystywane przez administrację centralną państwa i jego siły zbrojne, kompleksy gospodarcze, zwłaszcza systemy sektora energetycznego, paliwowego, chemicznego i transportowego oraz kreujące tzw. łańcuchy zdarzeń kryzysowych. Sposobem prowadzenia działań zapożyczonym $\mathrm{z}$ amerykańskich rozwiązań jest korzystanie z prywatnych firm wojskowych (ang. private military company, PMC) i ochroniarskich (ang. private military and security company, PMSC) ${ }^{16}$.

W sferze działań obronnych dominuje natomiast koncepcja dotycząca budowy zdolności antydostępowych $\mathrm{w}$ dwóch równoległych wersjach. Pierwszą niezmiennie pozostaje tworzenie stref buforowych wokół zewnętrznych granic FR. Drugą, wdrażaną obecnie, jest stosowanie rozwiązań A2/AD w wariancie tzw. obronnych działań zaczepnych. Podstawowym założeniem rosyjskiej koncepcji jest przesuwanie własnej strefy obrony, czemu towarzyszy poszerzanie strefy wpływów, osiągane przez zwiększanie potencjalnego obszaru rażenia (dyslokacje uzbrojenia lub jego wymiana na takie, które ma lepsze właściwości taktyczne lub większy zasięg). Drugą cechą rosyjskiego systemu antydostępowego jest konsolidacja potencjału militarnego różnych rodzajów sił zbrojnych i wojsk stacjonujących na danym obszarze, zwłaszcza systemów: obserwacji i wskazania celów, obrony przeciwlotniczej, walki radioelektronicznej, obrony wybrzeża oraz zestawów rakiet taktycznych. Analizując tę formułę budowy rosyjskiego potencjału antydostępowego, należy wskazać jego dwie kolejne cechy. Pierwszą jest duża samodzielność operacyjna na poszczególnych regionalnych teatrach działań wojennych, uzyskiwana dzięki tworzeniu swoistych centrów militarnych, które w rosyjskiej myśli wojskowej określa się mianem twierdz ${ }^{17}$. Drugą natomiast jest specyficznie tworzony potencjał militarny w tych regionach. Formalnie ma on charakter obronny, ale daje również możliwość prowadzenia działań ofensywnych lub wyprzedzających. Trzonem sił realizujących zadania antydostępowe są bowiem jednostki sił specjalnych, które są wspierane potencjałem broni precyzyjnego rażenia. Na ogół w tych regionach jest rozmieszczony wielowarstwowy potencjał rakietowy i służący do walki radioelektronicznej, wzmocniony siłami konwencjonalnymi oraz dobrze dobranym zabezpieczeniem logistycznym. Ten potencjał tworzą zazwyczaj:

- brzegowe systemy rakietowe zdolne do prowadzenia uderzeń na poziomie taktycznym, operacyjnym i strategicznym (zasięg od 150 do $600 \mathrm{~km}$ );

- systemy walki elektronicznej przygotowane do prowadzenia działań na poziomie operacyjno-taktycznym oraz do zakłócania systemów łączności i satelitarnych systemów nawigacyjnych;

16 Zob. S. Sukhankin, "A black cat in the dark room". Russian Quasi-Private Military and Security Companies (PMSCs) - 'Non-existent,' but Deadly and Useful, National Defence and the Canadian Armed Forces, http://www.journal.forces.gc.ca/vol19/no4/page43-eng.asp [dostęp: 12 XII 2020].

17 Dla rosyjskiej doktryny obronnej najważniejszymi twierdzami są: Obwód Kaliningradzki, Półwysep Krymski, Jakucja i Kamczatka. 
- siły okrętowe i powietrzne, których potencjał bojowy zależy od uwarunkowań geograficznych i fizycznych kontrolowanego obszaru (uzbrojenie rakietowe, potencjał desantowy itp.);

- systemy obserwacji powietrznej i obrony przeciwlotniczej, które mają zdolność do ograniczania możliwości rozpoznania powietrznego;

- systemy obserwacji nawodnej o zasięgu do $300 \mathrm{~km}$ oraz systemy obserwacji podwodnej;

- siły obrony lądowej, których potencjał bojowy zależy od specyfiki regionu i potencjalnych zdolności bojowych przeciwnika.

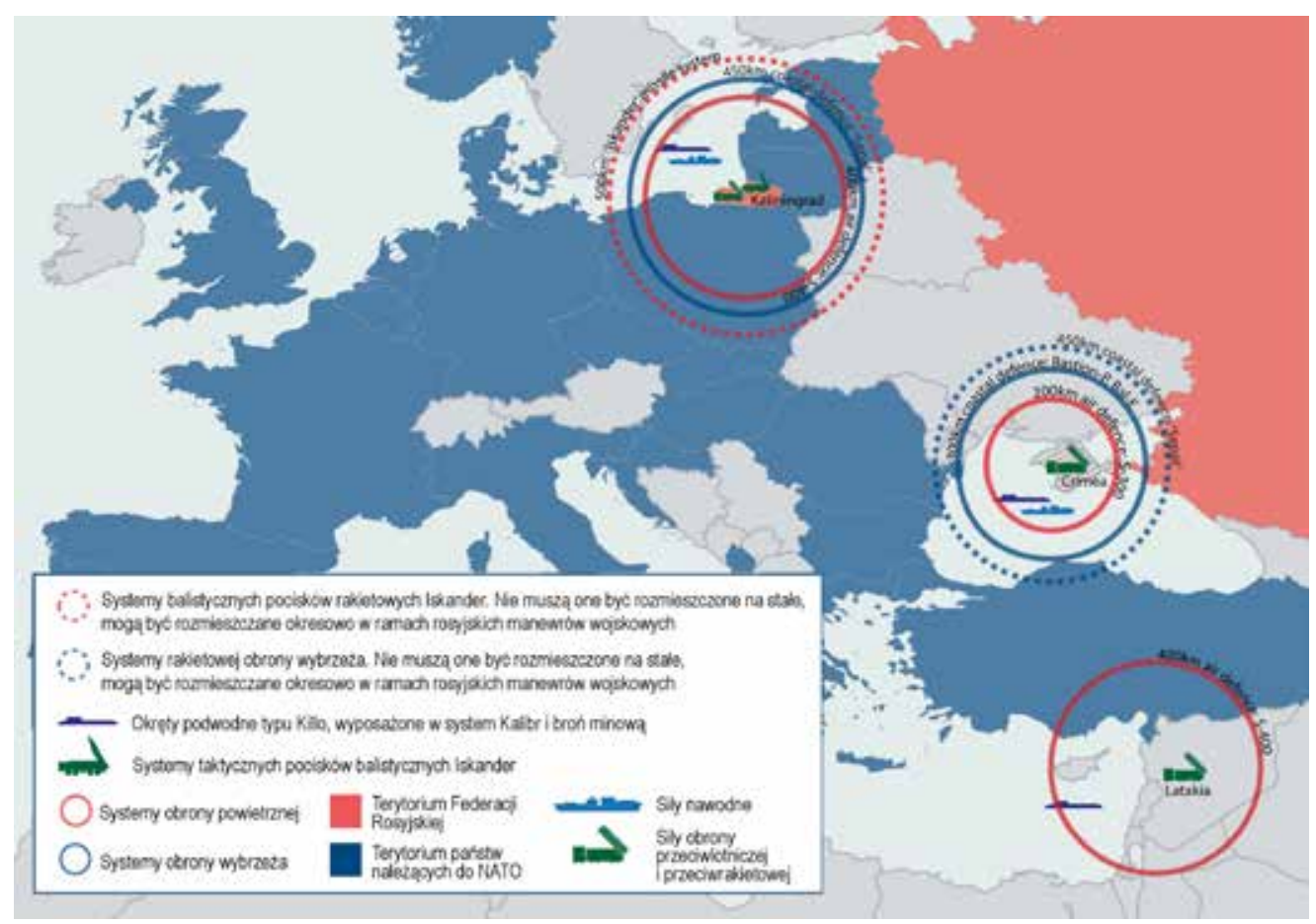

Rysunek. Rosyjskie strefy A2/AD w Europie Środkowo-Wschodniej i na Bliskim Wschodzie.

Źródło: The Military Balance 2015, International Institute for Strategic Studies, luty 2015.

Przedstawione na powyższym rysunku strefy antydostępowe na zachodnim kierunku obrony pełnią określoną funkcję w systemie aktywnej obrony. Wyposażenie bojowe rozlokowane w twierdzach w Kaliningradzie, na Krymie, w Noworosyjsku oraz w Latakii umożliwia prowadzenie nie tylko działań A2/AD, lecz także realizację przedsięwzięć o charakterze ofensywnym, wykraczających poza formułę aktywnej obrony. We wspomnianych bazach są skoncentrowane środki oddziaływania przeciwlotniczego, przeciwrakietowego, zwalczania sił morskich i prowadzenia walki radioelektronicznej, ale równocześnie są one przygotowane do realizowania działań stricte ofensywnych (możliwość przerzutu i bazowania sił) oraz polityczno-militarnych. Ma to pozwolić 
na kreowanie sytuacji $\mathrm{w}$ regionie oraz stwarzanie napięcia politycznego $\mathrm{w}$ formule incydentów polityczno-militarnych. Należy więc przyjąć, że rozwijanie koncepcji budowy stref antydostępowych w postaci tzw. twierdz było pochodną zmian w sposobie myślenia rosyjskiego kierownictwa polityczno-wojskowego. Zostało to jednoznacznie wyeksponowane w doktrynie wojennej FR z 2014 r. ${ }^{18}$, która de facto była próbą przełożenia teorii dotyczących koncepcji wojny nowego typu na praktyczne działania rosyjskich sił zbrojnych. Analizując jej treść w odniesieniu do działań sił zbrojnych, można zauważyć, że zapowiedziano w niej przygotowanie tych sił do prowadzenia działań opartych na tzw. koncepcji aktywnej (agresywnej) obrony, czyli równoległego prowadzenia działań ofensywnych i defensywnych. Wskazano także na konieczność zmiany podejścia do zagadnienia wyposażenia sił zbrojnych oraz, co ważniejsze, niezbędność ścisłego skorelowania zapisów zawartych $\mathrm{w}$ tej doktrynie $\mathrm{z}$ innymi dokumentami strategicznymi państwa ${ }^{19}$. W porównaniu z poprzednią doktryną istotną zmianą było podkreślenie roli innych niż nuklearne środków odstraszania jako instrumentu polityki bezpieczeństwa ${ }^{20}$. Jednoznaczne stwierdzenie, że samo dysponowanie określonym potencjałem nuklearnym nie gwarantuje bezpieczeństwa państwa, jest istotnym novum. Należy więc przyjąć, że za takowy instrument uznano także nowoczesne siły konwencjonalne, przygotowane do szybkiego reagowania zarówno na obszarze FR, jak i poza jej granicami. Analiza wspomnianej doktryny prowadzi do wniosku, że mogą one być użyte również w celu likwidacji zagrożeń wskazanych w tym dokumencie, w tym tłumienia separatyzmów i rebelii oraz reagowania na zagrożenie rosyjskich interesów $\mathrm{w}$ dowolnym regionie świata ${ }^{21}$. Przyjęcie takiego rozwiązania wymagało uzupełnienia składu poszczególnych związków operacyjnych o komponent sił szybkiego reagowania oraz utrzymania wysokiego stopnia gotowości bojowej. Osiągnięciu tych zdolności ma służyć przeprowadzanie licznych manewrów zakrojonych na szeroką skalę oraz niezapowiedzianych ćwiczeń, które jednocześnie mają być sposobem na zademonstrowanie siły. Ich celem jest również sprawdzenie gotowości bojowej poszczególnych jednostek.

18 Указ Президента Российской Федерации N Пр-2976 от 25 декабря 2014 г., „Военная доктрина Российской Федерации", http://static.kremlin.ru/media/events/files/41d527556bec8deb3530.pdf [dostęp: 12 III 2021].

19 Tamże, rozdział I, pkt 4. W doktrynie wojennej, o której mowa, zostały uwzględnione podstawowe założenia: koncepcja długoterminowego rozwoju społeczno-gospodarczego FR do 2020 r., strategia bezpieczeństwa narodowego FR do 2020 r., jak również odpowiednie regulacje dotyczące: polityki zagranicznej FR, doktryny morskiej FR do 2020 r., strategii rozwoju strefy arktycznej FR i zapewnienia bezpieczeństwa narodowego do 2020 r. oraz innych dokumentów planowania strategicznego.

20 Tamże, rozdział I, pkt 8, ppkt m. System odstraszania (powstrzymywania) niejądrowego - zespół przedsięwzięć polityki zagranicznej, przedsięwzięć wojskowych i wojskowo-technicznych, które są ukierunkowane na zapobieżenie środkami niejądrowymi agresji przeciwko FR.

${ }^{21}$ Zagrożenia bezpieczeństwa FR są scharakteryzowane w rozdziale II omawianej doktryny, w punktach: $9,10 \mathrm{i} 11$. W punkcie 12 zaprezentowano główne zewnętrzne niebezpieczeństwa wojenne, a w punkcie 13 - główne wewnętrzne niebezpieczeństwa wojenne. Opis podstawowych zagrożeń wojennych znajduje się w punkcie 14 . 
Te elementy pozwoliły na modyfikację strategii aktywnej obrony, która została zaprezentowana w marcu 2019 r. $^{22}$

Obecnie obowiązująca strategia zakłada wykorzystanie „zestawu środków do proaktywnego neutralizowania zagrożeń bezpieczeństwa państwa"23. Podkreśla się w niej, że jest ona reakcją na wzrastające zagrożenie ze strony państw wspólnoty transatlantyckiej (co jest stałym elementem narracji uzasadniającej wymóg zwiększenia potencjału militarnego FR) i wskazuje się hybrydowość kreowanych zagrożeń (zmienność zagrożeń kreowanych przez Zachód). Rosyjscy stratedzy wojskowi uznali, że specyfika tych zagrożeń wymusza wprowadzenie zmian w koncepcji dotyczącej reagowania na nie. Niezbędne jest zarzucenie - stosowanej wcześniej - polityki reagowania polityczno-militarnego na zdarzenia niepożądane z punktu widzenia interesu rosyjskiego, które zaistniały na obszarze ulokowania interesów FR lub istotnym dla jej bezpieczeństwa. Została ona zastąpiona ideą polityki służącej zapobieganiu możliwości wystąpienia takich zagrożeń. Wizja tzw. aktywnego reagowania na procesy mogące wywoływać zagrożenia przewiduje korzystanie z całej gamy środków oddziaływania militarnego i niemilitarnego, dobieranych stosownie do charakteru tych procesów ${ }^{24}$.

Strategia aktywnej obrony FR, przedstawiana jako stricte defensywna odpowiedź na politykę NATO i USA, zakłada możliwość wyprzedzającego (prewencyjnego) użycia sił zbrojnych w następstwie oceny sytuacji strategicznej. Istotą planowania strategicznego staje się utrzymanie lub przejęcie inicjatywy strategicznej w sytuacji narastania kryzysu. W tym przypadku rosyjscy stratedzy mają na myśli skorelowane przedsięwzięcia polityczno-ekonomiczno-militarne, których celem jest strategiczne powstrzymywanie i wyprzedzające neutralizowanie zagrożeń bezpieczeństwa narodowego państwa. Jednak najważniejszym zadaniem jest przesuwanie zewnętrznego pierścienia obrony (poszerzanie go) w kierunku potencjalnego przeciwka. Jest to realizowane przez wzmacnianie potencjału bojowego, zwłaszcza w postaci broni precyzyjnego rażenia o zwiększonym zasięgu, oraz tworzenie obszaru buforowego za pomocą politycznego lub ekonomicznego zwasalizowania państw graniczących z FR.

Swoistym, gdyż jest to koncepcja lansowana przez część tzw. postępowych kręgów eksperckich, odwołujących się do wizji wojny nowej generacji ${ }^{25}$, uzupełnieniem strategii aktywnej obrony jest strategia działań ograniczonych. Zdaniem przedstawicieli tego środowiska powinna ona zakładać prowadzenie działań zewnętrznych w celu

22 Strategię zaprezentował osobiście Szef Sztabu SZ FR gen. Gierasimow w trakcie dorocznego wystąpienia w rosyjskiej Akademii Nauk Wojskowych 2 marca 2019 r. Zob. В. Герасимов, Векторы развития военной стратегии, „Красная звезда”, 4 III 2019 r., http://redstar.ru/vektory-razvitiya-voennoj-strategii/?attempt=1 [dostęp: 1 V 2020].

23 Tamże.

24 Tamże.

25 Liderem tej grupy był gen. Władimir Slipczenko, twórca teorii wojny bezkontaktowej oraz wojny szóstej generacji, ale należy wskazać także generałów Walerija Gierasimowa i Siergieja A. Bogdanowa oraz płk Siergieja G. Czekinowa. Byli oni twórcami koncepcji operacji informacyjno-uderzeniowej. 
zarówno ochrony, jak i promowania rosyjskich interesów za granicą ${ }^{26}$. Po przeanalizowaniu wypowiedzi gen. Gierasimowa oraz ekspertyz rosyjskich strategów, zwłaszcza tych odnoszących się do doświadczeń wynikających z przebiegu konfliktu w Syrii ${ }^{27}$, można stwierdzić, że obecnie ta koncepcja jest integralnym elementem rosyjskiej polityki bezpieczeństwa. Wydaje się, że w sytuacji narastania kryzysu w obszarze ulokowania rosyjskich interesów głównym scenariuszem działania będzie groźba podjęcia bezpośredniej interwencji wojskowej. Nie zawsze będzie ona tożsama z samą interwencją, gdyż ma to być przede wszystkim sposób na zademonstrowanie siły i woli podjęcia działań. Należy się więc zgodzić z tezami Marena Garberga Bredesena i Karsten Friis, że groźba interwencji odgrywa w rosyjskiej strategii oddziaływania międzynarodowego rolę pomocniczą dla działań prowadzonych z wykorzystaniem środków niemilitarnych ${ }^{28}$.

Tab. 2. Doświadczenia płynące z działań militarnych w Syrii.

\begin{tabular}{|l|l|}
\hline \multicolumn{1}{|c|}{ Element zdobytego doświadczenia } & \multicolumn{1}{c|}{ Komentarz } \\
\hline $\begin{array}{l}\text { Zdobycie i przetestowanie zdolności do uzyska- } \\
\text { nia przewagi w procesie zarządzania konfliktem } \\
\text { i dowodzenia działaniami }\end{array}$ & $\begin{array}{l}\text { Celem uzyskania przewagi jest podejmowanie } \\
\text { właściwszych (w stosunku do przeciwnika) } \\
\text { i szybszych decyzji, co ma wymusić na dowódz- } \\
\text { twie strony przeciwnej poruszanie się w rosyjskich } \\
\text { ramach decyzyjnych. } \\
\text { Uzyskanie przewagi w procesie zarządzania } \\
\text { konfliktem i dowodzenia działaniami ma być } \\
\text { głównym celem w początkowej fazie konfliktu. } \\
\text { Przyjęto, że sprawność dowodzenia i kontroli (C2) } \\
\text { jest najważniejszym predyktorem sukcesu w ope- } \\
\text { racjach przeprowadzanych zarówno obecnie, jak } \\
\text { i tych w przyszłości }\end{array}$ \\
\hline
\end{tabular}

26 В. Герасимов, Векторы развития военной стратегии...

27 Przede wszystkim chodzi o wnioski dotyczące modernizacji systemów C4ISR (z ang. Command, Control, Communications, Computers, Intelligence, Surveillance and Reconnaissance, pol. dowodzenie, kontrola, komunikacja, komputery, wywiad, nadzór i rozpoznanie - przyp. red.), systemów robotycznych i UAV ( $\mathrm{z}$ ang. unmanned aerial vehicle, pol. bezzałogowy statek powietrzny - przyp. red.) oraz modyfikację sposobu prowadzenia operacji humanitarnych i działań z zakresu conflict management za granicą. Ciekawą analizą na ten temat jest raport opracowany przez Institute for the Study of War, opublikowany w styczniu 2021 r. Zob. M. Clark, The Russian Military's Lessons Learned In Syria, Washington 2021, http://www.understandingwar.org/sites/default/files/The\%20 Russian\%20Military\%E2\%80\%99s\%20Lessons\%20Learned\%20in\%20Syria_0.pdf [dostęp: 10 III 2021].

28 Zob. szerzej: M.G. Bredesen, K. Friss, Missiles, Vessels and Active Defence. What Potential Threat Do the Russian Armed Forces Represent?, „The RUSI Journal” 2020, nr 5-6, s. 68-78, https://www. tandfonline.com/doi/full/10.1080/03071847.2020.1829991 [dostęp: 10 III 2021]; D. Massicot, Anticipating a New Russian Military Doctrine in 2020: What It Might Contain and Why It Matters, War on the Rocks, 9 IX 2019 r., https://warontherocks.com/2019/09/anticipating-a-new-russian-military-doctrine-in-2020-what-it-might-contain-and-why-it-matters/ [dostęp: 10 III 2021]. 


\begin{tabular}{|l|l|}
\hline \multicolumn{1}{|c|}{ Element zdobytego doświadczenia } & \multicolumn{1}{|c|}{ Komentarz } \\
\hline $\begin{array}{l}\text { Koordynacja i sposób zawiązywania formalnych } \\
\text { koalicji w przyszłych wojnach }\end{array}$ & $\begin{array}{l}\text { Przyjętym wariantem jest zastąpienie koncepcji } \\
\text { „wojny zastępczej” (ang. proxy war) przez projek- } \\
\text { cję siły i działania koalicji chętnych. } \\
\text { Obecnie jest to realizowane w postaci wspólnych } \\
\text { ćwiczeń dotyczących sposobu prowadzenia opera- } \\
\text { cji koalicyjnych w ramach manewrów wojskowych } \\
\text { oraz poszerzania międzynarodowych powiązań } \\
\text { wojskowych }\end{array}$ \\
\hline $\begin{array}{l}\text { Uzyskanie doświadczenia bojowego przez jak naj- } \\
\text { liczniejsze komponenty sił konwencjonalnych }\end{array}$ & $\begin{array}{l}\text { Działanie określane jako „optymalizacja dyslokacji } \\
\text { wojsk" miało na celu skierowanie w rejon działań } \\
\text { bojowych jak największej liczby oddziałów. W tym } \\
\text { celu stosowano rotacyjne rozmieszczanie oddzia- } \\
\text { łów oraz rotację oficerów. To pozwoliło na uzy- } \\
\text { skanie przez znaczną część korpusu oficerskiego } \\
\text { szczebla operacyjnego i taktycznego doświadcze- } \\
\text { nia w sposobie planowania i prowadzenia działań } \\
\text { w operacjach innych niż wojenne }\end{array}$ \\
\hline $\begin{array}{l}\text { Wykorzystanie doświadczeń w procesie szkolenia } \\
\text { bojowego }\end{array}$ & $\begin{array}{l}\text { Wnioski istotne dla procesu planowania } \\
\text { i prowadzenia działań bojowych były na bieżąco } \\
\text { weryfikowane w trakcie ćwiczeń, a następnie } \\
\text { wkomponowywane w plany operacyjne. Należy się } \\
\text { spodziewać, że część z nich zawiera obowiązujący } \\
\text { Plan obrony Federacji Rosyjskiej na lata 2021-2025 } \\
\text { obowiązuje od 1 I 2021 r.) }\end{array}$ \\
\hline cji połączonych & $\begin{array}{l}\text { W trakcie ćwiczeń zwracano szczególną uwagę } \\
\text { na możliwości prowadzenia operacji na obszarze } \\
\text { o skomplikowanej sytuacji polityczno-militarnej }\end{array}$ \\
\hline
\end{tabular}

Źródło: Opracowanie własne na podstawie: M.G. Bredesen, K. Friss, Missiles, Vessels and Active Defence. What Potential Threat Do the Russian Armed Forces Represent?, „The RUSI Journal” 2020, nr 5-6, s. 68-78, https://www.tandfonline.com/doi/full/10.1080/03071847.2020.1829991 [dostęp: 10 III 2021]; M. Clark, The Russian Military's Lessons Learned In Syria, Washington 2021, http://www.understandingwar.org/ sites/default/files/The\%20Russian\%20Military\%E2\%80\%99s\%20Lessons\%20Learned\%20in\%20Syria_0. pdf [dostęp: 10 III 2021]; D. Massicot, Anticipating a New Russian Military Doctrine in 2020: What It Might Contain And Why It Matters, War on the Rocks, 9 IX 2019 r., https://warontherocks.com/2019/09/anticipating-a-new-russian-military-doctrine-in-2020-what-it-might-contain-and-why-it-matters/ [dostęp: 10 III 2021]; В. Герасимов, Векторы развития военной стратегии, „Красная звезда”, 4 III 2019 r., http://redstar.ru/vektory-razvitiya-voennoj-strategii/?attempt=1 [dostęp: 1 V 2020].

Decydujący wpływ na skuteczną realizację koncepcji strategii aktywnej obrony mają zarówno umiejętne prowadzenie polityki międzynarodowej oraz rozbudowa potencjału bojowego, zwłaszcza zaawansowanych systemów uzbrojenia, jak i poziom wyszkolenia bojowego sił zbrojnych. Te wszystkie elementy zostały uwzględnione $\mathrm{w}$ strategii bezpieczeństwa i realizowanych programach ${ }^{29}$. W odniesieniu do sfery militarnej należy wskazać zapisy dotyczące wdrażanych programów modernizacyjnych, rozwojowych oraz reformy struktury organizacyjnej sił zbrojnych. Skutkiem podjętych działań miało być uzyskanie przez wszystkie siły zbrojne zdolności do prowadzenia

29 Zob. szerzej: Rosyjska myśl strategiczna i potencjat militarny... 
operacji zintegrowanych z wykorzystaniem różnych rodzajów sił zbrojnych i wojsk. Głównym czynnikiem determinującym te procesy jest założenie, że we współczesnych konfliktach o zwycięstwie decydują: poziom gotowości bojowej armii, zdolność do uzyskania przewagi informacyjnej i technologicznej oraz posiadanie możliwości precyzyjnego rażenia w trybie stand-off nie tylko sił nieprzyjaciela, lecz przede wszystkim elementów jego infrastruktury krytycznej. Oceniając ich zakres, trzeba wziąć pod uwagę rolę, jaką przypisano zmianom w systemie dowodzenia i kontroli nad siłami zbrojnymi. Wdrożono rozwiązania ujednolicające struktury dowodzenia na poziomie strategicznym i operacyjnym. Przekształcenia objęły również Sztab Generalny Sił Zbrojnych FR - zmieniono jego usytuowanie i zakres kompetencji ${ }^{30}$. Za istotne rozwiązanie należy uznać stworzenie (umownego) poziomu strategiczno-operacyjnego, który stanowi pięć dowództw pełniących w trakcie pokoju funkcję okręgów wojskowych. Podporządkowano im prawie wszystkie siły rozmieszczone na ich obszarze (związki operacyjne: wojsk lądowych, wojsk kosmicznych, marynarki wojennej oraz związki operacyjne i samodzielne oddziały specjalistycznych rodzajów wojsk, jak np. rozpoznania, dowodzenia i łączności, walki radioelektronicznej, wojsk specjalnych) ${ }^{31}$. $\mathrm{Na}$ poziomie taktycznym powrócono natomiast do formowania dywizji pancernych i zmechanizowanych, które miały stanowić uzupełnienie istniejących brygad. Ta decyzja jest elementem procesu wdrażania wniosków z doświadczeń wyniesionych z działań bojowych w Donbasie, zwłaszcza z działań batalionowych grup bojowych i brygad oraz ich ograniczonych możliwości przełamywania silnie umocnionych pozycji obronnych przeciwnika. Należy również zgodzić się z opinią amerykańskich analityków, że wspomniane rozwiązanie wynika także z oceny struktury organizacyjnej armii państw NATO ${ }^{32}$. Tego typu związek taktyczny dysponuje bowiem pewną przewagą technologiczną nad porównywalnymi związkami taktycznymi państw Sojuszu.

${ }^{30}$ Jako centralny organ dowodzenia odpowiada on także za koordynację działań z innymi podmiotami zewnętrznymi. W toku reorganizacji usprawniono przepływ informacji i proces podejmowania decyzji oraz doprecyzowano podział kompetencji, dzięki czemu zwiększyło się tempo podejmowania istotnych decyzji i ich realizacji w postaci konkretnych rozkazów. W strukturze Sztabu Generalnego SZ FR znalazł się m.in. Komitet Wojskowo-Naukowy, odpowiadający za koordynowanie zarówno systemu kształcenia i szkoleń, jak i prac naukowo-badawczych dotyczących bezpieczeństwa i obronności państwa.

31 Wyjątkiem są dowództwa związków operacyjnych i taktycznych podległych bezpośrednio dowództwom, takim jak: Dowództwo Sił Specjalnych Operacji, Dowództwo Sił Powietrzno-Kosmicznych, Dowództwo Strategicznych Wojsk Rakietowych oraz Dowództwo Wojsk Powietrznodesantowych. W tych przypadkach podlegają one dowódcom operacyjno-strategicznym tylko w sprawach związanych $\mathrm{z}$ ich przebywaniem na danym obszarze. Zob. Rosyjska myśl strategiczna i potencjał militarny...

32 C. Harris, F.W. Kagan, Russia's Military Posture: Ground Forces Order of Battle, Institute for the Study of War, Washington 2018, s. 8-18; Западный военный округ, https://web.archive.org/ web/20170419224721/http://www.milkavkaz.net/2015/12/zapadnyj-voennyj-okrug.html [dostęp: 21 VII 2020]; Powrót wielkich jednostek. Rosja formuje sztaby armii i korpusów [ANALIZA], Defence 24, 29 I 2017 r., https://www.defence24.pl/powrot-wielkich-jednostek-rosja-formuje-sztaby-armii-i-korpusow-analiza [dostęp: 21 VII 2020]. 
Zwłaszcza że - pomimo rozmaitych ograniczeń, głównie finansowych i logistycznych - w dużym stopniu przeprowadzono modernizację techniczną armii, priorytetowo traktując modernizację w Zachodnim Okręgu Wojskowym oraz Południowym Okręgu Wojskowym ${ }^{33}$. Mimo że nie udało się osiągnąc zakładanych wskaźników nasycenia (70 proc.) nowoczesnym sprzętem poszczególnych rodzajów sił zbrojnych i wojsk, to w trakcie realizacji programu ГПВ-2020 (ros. Государственной программы вооружения на 2011-2020 годы, pol. Państwowy program uzbrojenia na lata 20112020) poziom tego nasycenia wyniósł: 83 proc. w Strategicznych Siłach Nuklearnych, 75 proc. w Siłach Powietrzno-Kosmicznych, 63 proc. w Siłach Powietrznych i Marynarce Wojennej i 50 proc. w Wojskach Lądowych ${ }^{34}$.

Po przeanalizowaniu powyższych danych można stwierdzić, że pomimo rozmaitych ograniczeń program został wdrożony. Istotniejsze jest jednak to, że w jego nowym wariancie - programie ГПВ-2027 (na lata 2021-2027) - uwzględniono istniejące zaległości, dostosowując go do rzeczywistego stanu modernizacji rodzajów sił zbrojnych i wojsk. W przeszłości takie podejście nie było oczywiste. Oceniając zakres reformy rosyjskich sił zbrojnych, należy również zwrócić uwagę na - pomijany w analizach proces przeobrażeń systemu szkolnictwa wojskowego. Przede wszystkim utrzymano jego pionową strukturę (uczelnie wyższe - wojskowe szkoły średnie i wyspecjalizowane wojskowe szkoły średnie), ale znacznie zmniejszono liczbę szkół ${ }^{35}$. Zasadniczą zmianą była jednak gruntowna wymiana kadry dydaktycznej, jej uzupełnienie osobami z praktycznym doświadczeniem bojowym oraz ścisłe powiązanie zakresu prac badawczych z celami programów modernizacji sił zbrojnych oraz założeniami przyjętymi przez Sztab Generalny SZ FR. Uczelnie wojskowe sukcesywnie stają się ośrodkami dydaktycznymi ukierunkowanymi na wykształcenie oficera przygotowanego do działań zgodnych z przyjętymi scenariuszami wykorzystania sił zbrojnych oraz ośrodkami

${ }^{33}$ Jak podaje gen. Jarosław Stróżyk, na sfinansowanie programu ГПВ-2020 zostały przewidziane środki w wysokości 20,7 bln rubli (ok. 681 mld dolarów), z czego dla resortu obrony przeznaczono 19,4 bln rubli (ok. 638 mld dolarów). Dodatkowe 3 bln rubli (98,7 mld dolarów) przeznaczono na odbudowę parku maszynowego kompleksu wojskowo-przemysłowego. Należy się zgodzić z uwagą tego eksperta, że tzw. złota era modernizacyjna, trwająca ok. 30 lat, skończyła się w 2015 r., z chwilą zmniejszenia budżetu Ministerstwa Obrony Federacji Rosyjskiej, która to tendencja utrzymała się także w następnych latach. Zob. J. Stróżyk, Ocena realizacji Programu Zbrojeń FR 2011-2020. Perspektywy modernizacji technicznej do 2025 roku, s. 2-3, Fundacja Bezpieczeństwa i Rozwoju Stratpoints, https://www.stratpoints.eu/publikacje/ocena-realizacji-programu-zbrojen-fr-2011-2020-perspektywy-modernizacji-technicznej-do-2025-roku/ [dostęp: 10 VII 2020].

34 Tamże. Dla przykładu, w 2019 r. na uzbrojenie wojsk lądowych i marynarki wojennej przewidziano ponad 1,5 biliona rubli (ponad 2 mld dolarów), a ponad $70 \%$ tych środków przeznaczono na zakup nowoczesnej seryjnej broni i sprzętu. Żołnierze otrzymali ponad 2300 jednostek nowego i zmodernizowanego sprzętu. W porównaniu z $2018 \mathrm{r}$. tempo podaży nowoczesnej broni wzrosło o 6,7\%. Na rozwój infrastruktury w 2019 r. przeznaczono łącznie 168 mld rubli (2,372 mld dolarów).

35 Obecnie (marzec 2021 r.) funkcjonuje: 28 wojskowych uczelni wyższych, 12 wojskowych szkół średnich (tzw. Federalne Suworowskie Szkoły Korpusu Kadetów) oraz 3 wojskowe wyspecjalizowane szkoły średnie. Zob. Ministry of Defence of the Russian Federation, Secondary Specialized Education, http://eng.mil.ru/en/education/specialized_secondary.htm [dostęp: 2 VIII 2020]. 
realizującymi badania dotyczące taktyki prowadzenia działań bojowych. Aktywność naukowo-badawcza jest koncentrowana na projektach związanych z nowymi formami prowadzenia działań bojowych, wyposażeniem bojowym żołnierza oraz z wymogami taktyczno-technicznymi dla nowego uzbrojenia ${ }^{36}$.

\section{Podsumowanie}

Po przeanalizowaniu procesu ewoluowania rosyjskiej doktryny wojennej między rokiem 2013 a 2020 należy wskazać na zmianę statusu poszczególnych metod konfrontacji. W 2013 r. za wiodące uznano środki polityczne, ekonomiczne oraz informacyjne, które miały być uzupełniane przez środki militarne i te o charakterze niemilitarnym. W koncepcji obowiązującej od 2018 r. podstawą działań jest natomiast skoordynowane użycie środków wojskowych i pozamilitarnych, przy czym decydującą rolę odgrywają siły zbrojne. Uznanie, że podstawową formą współczesnego i przyszłego konfliktu polityczno-militarnego będzie konflikt nieliniowy o dynamicznym przebiegu, spowodowało, że ważną rolę przypisano możliwościom stosowania instrumentarium kinetycznego, niekinetycznego oraz operacjom specjalnym o kompleksowym charakterze. Zgodnie z tym założeniem konieczne stało się dostosowanie sposobu funkcjonowania systemu dowodzenia armią i przygotowanie dowódców do prowadzenia operacji połączonych, realizowanych przez kombinowane zgrupowania wojsk, jak również poszerzenie możliwości prowadzenia całościowego, zintegrowanego rażenia sił nieprzyjaciela. Doświadczenia płynące z działań w Donbasie i Syrii pokazały także, że posiadanie tego rodzaju uzbrojenia nie gwarantuje sukcesu prowadzonym operacjom i musi być połączone $\mathrm{z}$ umiejętnym dowodzeniem siłami oraz z ich wysoką gotowością bojową. Wnioski wyciągnięte $\mathrm{z}$ tych doświadczeń oraz przeanalizowanie trendów rozwojowych sił zbrojnych głównych rywali doprowadziły do gruntownej zmiany wizji reformy rosyjskiej armii, która nastąpiła w 2019 r. Jej najistotniejszym postulatem jest odejście od prymatu zsynchronizowanych działań niemilitarnych w ramach niekinetycznej operacji destabilizacyjnej. Główny sposób prowadzenia tego typu operacji został oparty na koncepcji skoordynowanego użycia środków wojskowych i pozamilitarnych, przy czym siły zbrojne odgrywają w nim rolę decydującą.

\section{Bibliografia}

Bredesen M.G., Friss K., Missiles, Vessels and Active Defence. What Potential Threat Do the Russian Armed Forces Represent?, „The RUSI Journal” 2020, nr 5-6, s. 68-78, https://www. tandfonline.com/doi/full/10.1080/03071847.2020.1829991 [dostęp: 10 III 2021].

36 Oszacowanie jakości tego kształcenia jest trudne, gdyż brakuje dokładnych danych, a okres wdrażania nowych rozwiązań jest zbyt krótki. 
Clark M., The Russian Military's Lessons Learned In Syria, Washington 2021, http://www.understandingwar.org/report/russian-military\%E2\%80\%99s-lessons-learned-syria [dostęp: 10 III 2021].

Czaputowicz J., Teorie stosunków międzynarodowych. Krytyka i systematyzacja, Warszawa 2008, Wydawnictwo Naukowe PWN.

Harris C., Kagan F. W., Russia's Military Posture: Ground Forces Order of Battle, Washington 2018, Institute for the Study of War.

Hoffman F., Conflict in the 21st century: The rise of hybrid wars, Arlington 2007, Potomac Institute for Policy Studies.

Kasprzycki D.D., Militarny aspekt rosyjskiej obecności w Arktyce w kontekście regionalnego bezpieczeństwa do 2018 r., „Rocznik Bezpieczeństwa Międzynarodowego” 2020, nr 2, s. 190-216.

Keplin J., Pawlak C., Hybrydowość wyzwaniem dla bezpieczeństwa przyszłości, „Biuletyn CDiS SZ" 2016, nr 2, s. 5-7.

Kofman M., Rojansky M., A Closer look at Russia's 'Hybrid War', „Kennan Cable” 2015, nr 7, https://www.files.ethz.ch/isn/190090/5-KENNAN\%20CABLE-ROJANSKY\%20KOFMAN.pdf [ [dostęp: 12 I 2021].

McCuen J.J., Hybrid Wars, „Military Review” 2008, nr 2, s. 107-113.

Mickiewicz P., Rosyjska polityka arktyczna - próba zdominowania regionu czy instrument polityki bezpieczeństwa?, w: Geopolityka Rosji i obszaru postsowieckiego, L. Sykulski (red.), Warszawa 2020, Zona Zero, s. 178-204.

Mickiewicz P., W poszukiwaniu teoretycznych podstaw rosyjskiego myślenia strategicznego ery W. Putina, „Rocznik Bezpieczeństwa Międzynarodowego” 2018, nr 2, s. 39-56.

Nemeth W.J., Future War and Chechnya: A Case for Hybrid Warfare, Monterey 2002, Naval Postgraduate School.

Pawlak C., Konflikt na wschodzie Ukrainy sztandarowym przykładem działań hybrydowych, „Rocznik Bezpieczeństwa Międzynarodowego” 2017, nr 1, s. 268-287.

Pawlak C., Keplin J., Aneksja Krymu w kontekście działań hybrydowych, „Kwartalnik Bellona” 2016, nr 3, s. 23-32.

Rosyjska myśl strategiczna i potencjał militarny w XXI wieku, P. Mickiewicz (red.), Warszawa 2018, Wydawnictwo Naukowe PWN.

Wojciuk A., Dylemat potęgi. Praktyczna teoria stosunków międzynarodowych, Warszawa 2010, Wydawnictwa Uniwersytetu Warszawskiego. 


\section{Źródła internetowe}

Massicot D., Anticipating a New Russian Military Doctrine in 2020: What It Might Contain and Why It Matters, War on the Rocks, 9 IX 2019 r., https://warontherocks.com/2019/09/anticipating-a-new-russian-military-doctrine-in-2020-what-it-might-contain-and-why-itmatters/ [dostęp: 10 III 2021].

Stróżyk J., Ocena realizacji Programu Zbrojeń FR 2011-2020. Perspektywy modernizacji technicznej do 2025 roku, https:/www.stratpoints.eu/publikacje/ocena-realizacji-programu-zbrojen-fr-2011-2020-perspektywy-modernizacji-technicznej-do-2025-roku/ [dostęp: 10 VII 2020].

Sukhankin S., "A black cat in the dark room". Russian Quasi-Private Military and Security Companies (PMSCs) - 'Non-existent,' but Deadly and Useful, National Defence and the Canadian Armed Force, http://www.journal.forces.gc.ca/vol19/no4/page43-eng.asp [dostęp: 12 XII 2020].

\section{Rosyjskie źródła internetowe}

Чекинов С.Г., Богданов С.А., Асимметричные действия по обеспечению военной безопасности России, „Военная мысль” 2010, nr 3, s. 13-22, http://militaryarticle.ru/ voennaya-mysl/2010-vm/10291-asimmetrichnye-dejstvija-po-obespecheniju-voennoj [dostęp: 10 X 2019].

Дульнев П.А., Ковалев В.Г., Ильин Л.Н., Асимметричное противодействие в сетецентрической войне, „Военная мысль” 2011, nr 10, s. 3-8, http://militaryarticle. ru/voennaya-mysl/2011-vm/10357-asimmetrichnoe-protivodejstvie-v-setecentricheskoj [dostęp: 11 X 2019].

Герасимов В., Векторы развития военной стратегии, „Красная звезда”, 4 III 2019 r., http:// redstar.ru/vektory-razvitiya-voennoj-strategii/?attempt=1 [dostęp: 1 V 2020].

Сергей Шойгу рассказал, как спасали российскую, 22 IX 2019 r., https://www.mk.ru/politics/2019/09/22/sergey-shoygu-rasskazal-kak-spasali-rossiyskuyu-armiyu.html [dostęp: 22 IX 2019].

Указ Президента Российской Федерации N Пр-2976 от 25 декабря 2014 г. „Военная доктрина Российской Федерации”, http://static.kremlin.ru/media/events/files/41d527556bec8deb3530.pdf [dostęp: 12 III 2021]. 


\begin{abstract}
Abstrakt
W artykule opisano ewolucję rosyjskiej koncepcji działań militarnych jako formy realizacji polityki bezpieczeństwa. Przedstawiono istotne zmiany w koncepcji dotyczącej prowadzenia działań hybrydowych w stosunku do sposobu, w jaki je realizowano podczas aneksji Półwyspu Krymskiego oraz rosyjskiej interwencji w Syrii. Wykazano, że obowiązująca od 2018 r. koncepcja przebudowy sił zbrojnych ma na celu ich przygotowanie do realizacji zarówno tzw. operacji zintegrowanych, poszerzania zewnętrznej strefy obrony, jak i operacji o charakterze antydostępowym. Służyć temu ma wyposażenie sił zbrojnych w odpowiednie środki, umożliwiające wykonywanie tak sformułowanych zadań, oraz wdrożenie strategii aktywnej obrony, zakładającej podejmowanie przez Rosję działań wyprzedzających na podstawie precyzyjnych algorytmów planowania. Uzupełnieniem rosyjskiej strategii aktywnej obrony jest strategia działań ograniczonych. Zdaniem rosyjskich ekspertów powinna ona zakładać prowadzenie działań zewnętrznych $\mathrm{w}$ celu ochrony oraz promowania rosyjskich interesów za granicą. Z przeprowadzonych analiz wynika, że Rosjanie uznali, że podstawową formą konfliktu polityczno-militarnego zarówno obecnie, jak i w przyszłości będzie konflikt nieliniowy o dynamicznym przebiegu. W związku z tym ważną rolę przypisano możliwościom stosowania instrumentarium kinetycznego i niekinetycznego oraz operacjom specjalnym o kompleksowym charakterze. W celu realizacji tych planów gruntownie zreformowano siły zbrojne. Zmieniono strukturę organizacyjną, system szkolenia i zmodernizowano uzbrojenie. Najważniejszy etap reform został ukończony, pomimo sankcji, w grudniu 2020 r. Na zmiany wprowadzane w rosyjskiej doktrynie wojskowej miały wpływ doświadczenia płynące z działań w Syrii i Donbasie. Przede wszystkim nastąpiło odejście od prymatu zsynchronizowanych działań niemilitarnych w ramach niekinetycznej operacji destabilizacyjnej. Obecnie główny sposób prowadzenia operacji polega na skoordynowanym użyciu środków wojskowych i pozamilitarnych, przy czym siły zbrojne odgrywają w takich operacjach decydującą rolę.
\end{abstract}

Słowa kluczowe: $\mathrm{A} 2 / \mathrm{AD}$, Rosja, działania konwencjonalne, działania nieliniowe, działania zintegrowane, reforma, siły zbrojne, strategia, doktryna. 


\title{
Evolving from hybrid conflict leading into conventional warfare? The Russian concept of military impact, with particular reference to the changes after 2018
}

\begin{abstract}
The article presents the evolution of the Russian idea of military operations as a form of implementing security policy. Significant changes in the concept of conducting hybrid operations were pointed out in relation to the way they were carried out in the process of the annexation of the Crimean Peninsula and during the Russian intervention in Syria. It was shown that the concept of the reconstruction of the armed forces since 2018 has been aimed at both preparing them for the implementation of the so-called integrated operations, expanding the external defence zone, and performing antiaccess operations. This is to be achieved by adequately saturating the armed forces with the necessary means to conduct such a task and by practically implementing the active defence strategy, which assumes that Russia will take pre-emptive actions based on precise planning algorithms. The Russian strategy of active defence is complemented by a strategy of limited operations. According to Russian experts, this strategy should involve external actions to protect and promote Russian interests abroad. The analyses demonstrate that the Russians have decided that the basic form of contemporary and future political-military conflict will be a non-linear conflict with a dynamic course. That is why a key role has been assigned to both kinetic and non-kinetic instrumentation capabilities and special operations with a comprehensive scope. To implement these plans, a thorough reform of the armed forces was carried out in terms of restructuring the organization, reforming the training system and modernizing the armaments. The main phase of the reforms had been successfully implemented by December 2020, despite the sanctions. The experience of Syria and the Donbass influenced the transformation of the Russian military doctrine. Its most important assumption was to move away from the primacy of synchronized non-military actions within a non-kinetic destabilizing operation. The concept of coordinated use of military and non-military means with a decisive role of the armed forces has become the basic form of conducting operations of this type.
\end{abstract}

Keywords: A2/AD, Russia, conventional operations, nonlinear operations, integrated operations, reform, armed forces, strategy, doctrine. 